\title{
Études/Inuit/Studies
}

\section{Is the Arctic really urbanising?}

\section{L'Arctique est-il vraiment en voie d'urbanisation?}

\section{Susanne Dybbroe}

Volume 32, numéro 1, 2008

Inuit urbains

Urban Inuit

URI : https://id.erudit.org/iderudit/029817ar

DOI : https://doi.org/10.7202/029817ar

Aller au sommaire du numéro

\section{Éditeur(s)}

Association Inuksiutiit Katimajiit Inc.

Centre interuniversitaire d'études et de recherches autochtones (CIÉRA)

ISSN

0701-1008 (imprimé)

1708-5268 (numérique)

Découvrir la revue

\section{Citer cet article}

Dybbroe, S. (2008). Is the Arctic really urbanising? Études/Inuit/Studies, 32(1), 13-32. https://doi.org/10.7202/029817ar

\section{Résumé de l'article}

L'anthropologie des sociétés inuit de l'Arctique perçoit de plus en plus une tendance générale à l'urbanisation à travers toute la région, tendance qui englobe les communautés locales à petite échelle aussi bien que les bourgades et les villes. Les Inuit migrent vers les villes extérieures à l'Arctique et vivent dans le Nord dans des conditions fortement teintées d'urbanisation. Les ouvrages universitaires et politiques suggèrent qu'il existe une relation de plus en plus étroite entre les résidents de l'Arctique et les villes. Après un survol historique des habitats permanents du Nunavut et du Groenland, afin d'illustrer l'intégration structurelle des sociétés arctiques, cet article démontre que l'urbanisation suit des trajectoires historiques spécifiques créant des situations urbaines différentes. L'auteure discute de la pertinence des concepts "d'urbanisation» et «d'urbanisme» lorsqu'on les applique à l'Arctique, et propose une perspective d'anthropologie urbaine susceptible de représenter une manière productive d'envisager les réalités sociales et culturelles mondialisées de l'Arctique contemporain.
Tous droits réservés @ La revue Études/Inuit/Studies, 2008
Ce document est protégé par la loi sur le droit d'auteur. L'utilisation des services d’Érudit (y compris la reproduction) est assujettie à sa politique d'utilisation que vous pouvez consulter en ligne.

https://apropos.erudit.org/fr/usagers/politique-dutilisation/ 


\title{
Is the Arctic really urbanising?
}

\section{Susanne Dybbroe*}

\section{Résumé: L'Arctique est-il vraiment en voie d'urbanisation?}

L'anthropologie des sociétés inuit de l'Arctique perçoit de plus en plus une tendance générale à l'urbanisation à travers toute la région, tendance qui englobe les communautés locales à petite échelle aussi bien que les bourgades et les villes. Les Inuit migrent vers les villes extérieures à l'Arctique et vivent dans le Nord dans des conditions fortement teintées d'urbanisation. Les ouvrages universitaires et politiques suggèrent qu'il existe une relation de plus en plus étroite entre les résidents de l'Arctique et les villes. Après un survol historique des habitats permanents du Nunavut et du Groenland, afin d'illustrer l'intégration structurelle des sociétés arctiques, cet article démontre que l'urbanisation suit des trajectoires historiques spécifiques créant des situations urbaines différentes. L'auteure discute de la pertinence des concepts «d'urbanisation» et «d'urbanisme» lorsqu'on les applique à l'Arctique, et propose une perspective d'anthropologie urbaine susceptible de représenter une manière productive d'envisager les réalités sociales et culturelles mondialisées de l'Arctique contemporain.

\begin{abstract}
Is the Arctic really urbanising?
The anthropology of the Arctic (Inuit) societies is increasingly acknowledging a general urbanising trend throughout the region, encompassing small-scale, localized, communities as well as towns and cities. Inuit migrate to cities outside the Arctic and live in the North under circumstances strongly tinged by urbanism. Policy and academic literature suggests that there is an increasingly close relation between Arctic residents and cities. After an historic overview of permanent settlement in Nunavut and Greenland to illustrate the structural integration of Arctic societies, this article points to the fact that urbanisation follows historically specific trajectories and creates different urban situations. The author discusses the relevance of the concepts "urbanisation" and "urbanism" to the Arctic, and proposes an urban anthropological perspective that offers a productive way to approach the globalised social and cultural realities of the contemporary Arctic.
\end{abstract}

Department of Anthropology and Ethnography, Aarhus University, Moesgård, DK-8270 Højbjerg, Denmark. etnosd@hum.au.dk

ÉTUDES/INUIT/STUDIES, 2008, 32(1): 13-32 


\section{Introduction}

Arctic societies have often been looked at as something in and for themselves, as people and communities that are caught up in local cultures. If we want to describe and understand the dynamics of modern Arctic living, this perspective must change, to a view that grasps these societies as integral to a global modernity that penetrates the very fabric of Arctic social life in all aspects: interpersonal relations; village and town life; wide-ranging market relationships; as well as openness to and participation in global communications networks. By virtue of its extensive connectedness, its complex division of labour, the diffusion in and out of many different cultures, and its dependence on modern information technology, this can only be called an urban way of life. The question of the usefulness of the concept of "urban" to Arctic societies is discussed in terms of present-day general conditions in the North and the ways in which this challenges approaches of a more relativist kind that are not able to represent the connectedness of modern Arctic living, and hence important elements in its dynamics.

\section{The setting and the background}

During field research in 1996 and 1997 in the West Greenlandic towns of Qeqertarsuaq and Maniitsoq I became increasingly interested in the issue of urbanism, as I attempted to deal with my topic of generational change and knowledge transmission among young people aged 13 to 18 years. Both towns exhibit features of urbanism as a quality of local life and experience, as opposed to "urbanisation" which is more a matter of settlement size, density and structure, if we follow much used criteria. Size does matter, of course: one at least of these towns, Maniitsoq, is so large and fluid that any attempt to describe it using a community study approach would require a major investment of time, at best. Such an approach could also not be expected to provide the theoretical framework that I needed in order to come to grips with, and describe from a unitary perspective, the variation in backgrounds, goals and resources that characterized the young people's family and social situations. To do that would have involved descriptions of criss-crossing commitments, revolving around criteria as foundational as class and kinship, and the latter's articulation with a broad spectrum of commitments of "primordial" loyalties (Dahl 1985).

Both places, Qeqertarsuaq, with 1,000 inhabitants, located on an island in Disco Bay and accessible by public transport on a twice-weekly basis, and Maniitsoq, with 3,000 inhabitants, located in central West Greenland and in open contact with the outside world on a daily basis, are towns in a modern world. They form part of a modern nation-state, their residents are continually interacting with the surrounding world through state and local bureaucracies, local, national and international politics, the market, family networks, schooling and education, ready access to transport networks, and access to (and input from) the electronic media. This is to mention just a few channels of interaction and communication in any ordinary small community, village or town, in Arctic societies today. A large fraction of the latter population is part

\section{4/S. DYBBROE}


of an urbanised, and increasingly globalised, social world. Not everybody enjoys its benefits, of course, and not all have access to it in the same degree, but all are subject to the way it works (Dahl 1986, 2000; Dorais 1997; Dyck 1984; Nuttall 1994; Paine 1977). The relevant approach for my purpose, in terms of both theory and method, is therefore an open-ended solution to the question of what constitutes society and the societal, building on other criteria of boundedness than are implied in classic community studies of small-scale northern settlements (Graburn 1969; Honigmann and Honigmann 1965, 1970; Vallee 1962). Community, in the sense in which I intend to use the word here, is defined not in terms of its physical properties and spatial lay-out, but, rather, in terms of the social integration of the place and the people into wider structures, both national and global.

If Greenlanders do live in an urbanised world, then it may be expected that the quality of their interactions with each other will resemble what the classical theorists understood as an urban way of life - since this is generally what is understood by the term (Simmel 1950[1903]; Wirth 1938). They fulfil specialised functions in a complex division of labour and interact with many different kinds of people, some of whom are totally unknown to them. The individual under urban circumstances is, supposedly, less constrained in her freedom to make choices than her counterpart in the "traditional" small place, whose neighbours and kin police the boundaries of the local moral community. Social relations and networks of exchange and communication of members of an urban society reach in all directions, within and outside of the immediate area of residence. The dimension of connectedness implied in all this, and widely theorized (Appadurai 1990; Robertson 1997), has a particular history in the Arctic that is contingent upon the spatial characteristics of northern societies (small and mobile, with great distances between groups) and the ways these have changed under colonial regimes. Welfare policies have made their imprint on northern societies and we see a degree of dispersion, articulating with new structures of communication and travelling, that opens up avenues for individuals to pursue goals outside the local community.

This article has emerged out of the confrontation between my observations and reflections during periods of fieldwork in West Greenland, and the recent policy and academic literature that describes Arctic societies as urbanising (Statistics Canada 2003: 8-11; Csonka and Schweitzer 2004). My concern is twofold: to discuss the relevance of the concepts of urbanisation and urbanism to the Arctic, and to raise some questions about the relevance of urban anthropological theory (assuming such a body of theory exists) to methodological issues facing anthropologists working in small-scale northern societies. I hope to demonstrate that the description and analysis of the cultural and social realities of Arctic communities may benefit if we take a perspective inspired by the anthropology of urban and complex societies, Arctic or otherwise.

In addition, I have been inspired in what follows by some very general, but perceptive remarks by David Riches. Discussing the wave of pioneering anthropological studies during the 1960s and 1970s, Riches identifies a "niching" trend, in which ethnographers became concerned with very specific topics such as "ethnohistory," "kinship in the Central Arctic," "Native art," "the Bering Strait," and so 
on. He argues that this trend "continues to the present. Its consequence is that Eskimo society and culture, thus compartmentalized by both topic and region, seldom gets overviewed-with the result that it comes to be hard to discern broader processes impinging on Eskimo society in general" (Riches 1990: 85). It is exactly these "broader processes" that I am concerned with in this article.

\section{Why ask the question?}

Urbanisation in the Arctic has been highlighted recently by the Aboriginal Peoples' Survey - 2001 (or APS) (Statistics Canada 2003) and the Arctic Human Development Report (or AHDR) (Einarsson et al. 2004). These reports are intended to initiate a knowledge base for the development of policies of sustainable human development: one is concerned with the growing number of Aboriginal Canadians in cities, and the issues of social participation, civil rights, etc., that are raised by this situation (Statistics Canada 2003: 8); the other takes a comprehensive view of the circumpolar Arctic states and Aboriginal citizens, in order to discuss present and future prospects of well-being for Arctic residents (Einarsson et al. 2004: 15). Of course, these are not the first studies of Inuit in urban environments. Eskimo Townsmen and Arctic Townsmen, by John and Irma Honigmann, published respectively in 1965 and 1970, documented the earliest development of permanent settlements in the Northwest Territories. More recently, a new field of research is developing, focusing on Inuit in big cities (Fienup-Riordan 2000; Fogel-Chance 1993; Kishigami 1999, 2002a, 2002b, 2006; Sørensen 2003a 2003b, 2003c, 2006). So, if urbanisation is already on the agenda, why ask the question?

The answer is, to clarify matters, in order to better define this field that is opening up to Arctic research, in terms of comparative theory and methodology. Urbanisation in these recent reports is viewed from a different perspective than that which characterised most earlier studies of Inuit in towns. The Honigmanns, and others, dealt with urbanism in terms of acculturation, emphasising the adaptation of Inuit values, norms and social organisation to urban settings that were dominated by a white colonial establishment (Graburn 1969; Honigmann and Honigmann 1965, 1970; Vallee 1962; Vanstone 1962). Urbanism, in a sense, was treated as an external condition to which Inuit accommodated. The point now is that Inuit communities are part of a generalised movement that has gained momentum in all the Arctic regions. Towns grow at a rapid pace, and people settle down in urban centres, often far away from their home areas (Csonka and Schweitzer 2004: 47ff; Statistics Canada 2003). Inuit societies are, in a word, urbanising. The definition of what constitutes the urban is in the hands of the statisticians, however. Csonka and Schweitzer (2004: 62) do not define what they called the "universal and well studied trend" of urbanisation, but use it to refer to demographic concentration accompanying the rise of welfare state policies, industrialisation, and wage employment.

According to the APS, "urban regions" areas outside of the Canadian Arctic have, first, a particular gross level of population (more than 1,000 inhabitants) and, second, a

\section{6/S. DYBBROE}


particular concentration of population (more than 400 people per square $\mathrm{km}$ ) that is characteristic of southern cities (Statistics Canada 2003: 10) ${ }^{1}$. What is more, the APS models the urbanisation of Aboriginal Canadians as a movement North-South, and specifically exempts the Inuit (Arctic) region (ibid.: 8ff). The meaning of this exemption becomes clearer if we consider the fact that along with urbanisation comes an extension of local communities through emigration (Csonka and Schweitzer 2004: $60 \mathrm{ff}$ ). Migrants keep up relations with their home communities, and channels of movement and communication are upheld both ways (Dahl 2000; Fienup-Riordan 2000; Fogel-Chance 1993; Kishigami 1999). This qualitative change is nicely summed up in the following comment, generalizing from East Greenland that "[...] life in concentrated settlements seems to have become the only social model for the inhabitants of Greenland" (Robert-Lamblin 1999: 35, my translation).

In the anthropological debate on urbanisation, numbers are not the issue, however: trans-local linkages and integration are (Leeds 1994). Urbanism is understood as an organisational mode that is specific to certain (urban) environments, an expression of human adaptation to, and participation in, wider ecological and societal structures (Hannerz 1980: chap. 3; Leeds 1994: 53ff). These theoretical perspectives on urbanism can inform our analyses of rapid social change in Greenland and Nunavut. In particular, qualitative and processual models of urbanisation-rather than quantitative, demographic definitions - offer useful insights into modern Arctic life under conditions of globalisation. For the sake of brevity, I shall concentrate on data from Maniitsoq, and questions that cropped up during my fieldwork there.

\section{Maniitsoq}

I came to the town of Maniitsoq in West Greenland in the winter of 1997 to study the exchange of knowledge and values between the first all-Home-Rule-generation of adolescents, and their parents and adults ${ }^{2}$. The idea was to frame a field that would allow me to study school-pupils' perspective on urban living, as I worked to understand how tradition, i.e., particular kinds of long-established knowledge and competence, was passed on to the younger generation ${ }^{3}$. My choice of Maniitsoq was prompted by a wish to study a town that had been at the centre of industrialisation, as it took place in central West Greenland during the 1960s and 1970s, when the fishery was industrialised. I had previously done fieldwork in a much smaller town in the Disco Bay area to the north,

1 According to Statistics Canada (2003: 8), Canada's Aboriginal population is "young, growing and increasingly urbanized." Almost 50\% live in urban areas in southern Canada. The so-called "least urbanised" are the Inuit, of whom about $20 \%$ live outside the Canadian Arctic, mostly in southern areas (ibid.).

2 Home Rule was instituted in May 1979. My primary interest group was school children in the oldest grades (8 through 11), who had grown up under a Greenlandic government.

3 The title of my project was The organisation of knowledge and the transmission of cultural competence in urban and local communities. It was part of a more comprehensive project about Environmental Knowledge, Cultural Strategies and Development in Greenland and the Circumpolar North, involving a team of researchers and funded by the Danish Research Councils' TUPOLAR programme. 
Qeqertarsuaq, as well as in Qaqortog in south Greenland (a town the size of Maniitsoq), and I had noted characteristic differences between the two places in household involvement in hunting and fishing, and the degree to which children and young people were participating in these activities. My research was intended, firstly, to produce primary data to inform a discussion of the anthropological construction of Indigenous or local knowledge; secondly, to compare the circumstances of growing up in villages and towns in terms of the different expectations of parents and children; and thirdly, to study continuity and change, articulated through individual concerns about, and hopes for, their present and future lives.

Maniitsoq is located across a rugged terrain and comprises a number of small islands, connected by bridges. Houses are built on level spots, and many wooden staircases traverse uneven levels between houses and streets. The oldest part of the town consists of single-family dwellings, built in wood and brightly coloured. Some areas of town have quarters of concrete apartment buildings, cramped together in tight rows. Most recent construction work is, however, built to resemble the traditional (colonial) style house; these are located on a more individual basis, to create villagelike quarters, as the town's physical boundaries move outward. Maniitsoq is a bustling town with people moving around at all hours of the day by car, skidoo, bicycle, or foot. In spring and summer, groups of children skateboard or roller-skate on the concrete roads connecting the quite far-flung built-up areas. On a good day weather-wise, you may hear through open windows music that tells you this is a place in close contact with the rest of the world. Walking along a street, you will notice the affluence, the smartness of dress. Just around the corner, the visitor's eye meets another sight, kalaalimineerniarfik - an outside place, often just a board or a piece of plywood, set up to display hunting products for sale.

Maniitsoq used to be the most important fishing town in West Greenland, until the big cod fishery collapsed in 1980. Fishing is still done on a smaller scale, with incomes now concentrated in fewer hands. Several commercial boats have been sold or given up. The structure of the fishing fleet has changed, too, from many large and medium sized trawlers to a very few, mostly fishing far away, and small boats. Other changes have resulted from recent policies of subsidizing small scale fishing, such as halibutcaught from medium size vessels or small boats - which at the time had become a commercial success story in some places.

The size of the town prevents a genuine observer's participation in the full spectrum of local activities. The harbour is far away, and hunters and fishermen come and go as unobtrusively as anybody in town. Information on who, where and what, does not come your way, unless you are neighbour, relative or partner. The situation is accentuated by the town's layout and architecture: located in a mountain landscape, houses are constructed at shifting levels or as medium sized high-rise apartment buildings, neither of which allow a close view of one's neighbours. On Sunday mornings, after a sleepless night with noise rolling back and forth between tallish buildings, you may not know whom to blame. This is all recognisable as very urban. The same goes for what looks, at first sight, to be a very "urban" group of teenagers.

\section{8/S. DYBBROE}


My preferred group of interaction while I was in Maniitsoq, their whereabouts and availability to me were structured by the accessibility of sports facilities, a youth club, and the fact that most families had one, maybe more, TV sets and video-players. An active group of youngsters travelled the coast during the softball and volleyball seasons, a smaller group trained at skiing for the Arctic Games to be held in Calgary the following year. A few pupils in school opted for trips abroad as exchange students, to Brazil, Kenya and the USA, for example.

Other sides of life in Maniitsoq do not, at first sight, correspond as obviously to the above, admittedly somewhat ethnocentric, view of the "urban." While social stratification, for example, reflects the recent local economic crisis and the evolution of post-colonial class relationships, it is complex, based also on merit (status), language proficiency (monolingual or bilingual), and occupation. These contrasting criteria of stratification might seem to lend themselves to interpretation within a discourse of "tradition" versus "modernity," but again, it is more complex. Kinship and family are important idioms and principles of traditional Inuit social organisation. Looking at family life, however, there were high drop-out rates from school by pupils, who have little support from their families, according to school authorities. Depending on the context and the social indicators, this judgment may be valid; in other cases involving young pregnant girls dropping out, a very supportive set of parents might be there, who advise their daughter to have the baby, leaving it up to her to go back to school, while the care of the grandchild for one or even several years is left with the grandparents. Inasmuch as this arrangement is a recurrent pattern, sometimes involving grandmothers who were themselves very young mothers, this suggests more complex interactions between "traditional" and "modern" expectations-the rhetoric of the educational system and policy is oriented towards achievement, whereas individuals deal with their life and future according to familial role models.

Hunting is, by many accounts, another "traditional" activity. At the time of fieldwork, the number of hunters had more than doubled within a few years, to about 70. However, hunting was no longer taught to boys growing up and many families could not take their children on boat trips or otherwise instruct them in local knowledge. The newly established hunters were, in fact, men of 30 to 40 years of age, or older, some of whom had previously worked on the trawlers that had been sold after the fishery collapsed. Some had hunted on a small scale for mostly household consumption, and now tried to establish themselves on a more professional basis. The organisation of this activity was in every respect modern. This was urban hunting, with well-organised marketing, an association of small-scale fishermen within the larger hunters' association, and so on; no sharing of the bag as a rule, perhaps the most basic collaboration to make up for competition. The home-rule policy of subsidising commercial hunting I take as one explanation of this renewal of an activity, which had for years in this town been reduced to more or less a niching income. Although hunting appears to be a traditional source of income, it may here be considered to be a "last ditch" strategy for finding an occupation. Tentative support for this assumption may be found in the fact that a few former trawler fishermen, who had established themselves 
as commercial hunters, had migrated to Denmark over the period of less than two years preceding my fieldwork, during which the small fishermen's association had existed.

So, in fact, there is nothing inherently traditional about hunting; it has proved to be perfectly adaptable to modern circumstances and market relationships, in principle combining the best of two worlds (Wenzel 1986). The term "subsistence," often meant to imply hunting for domestic consumption, has created a confusing scenario in which hunting is seen to be indicative of tradition, but actually subsistence has for a long time only been possible in relation to a market (Dybbroe and Møller 1981). There are many reasons other than economic necessity for the importance that may be attached to hunting, including the symbolic, the political and the emotional. However, hunting may be totally organised by the requirements of the market, and the decisions and choices made by hunters follow other logics than those that are imputed by reference to tradition. While the market itself may appear to be wholly informal, it is well organised, the salesmen are hired hands who are paid on a commission basis, and hunters keep informed of what is in demand on any particular day. "Traditional" versus "modern" does not seem to direct our study towards the motives involved in people's reactions to changes in their situation. Loss of tradition is not but may perhaps be change for the better, or at least necessary change. As noted by Csonka and Schweitzer (2004: 50ff), research has focused too little on peoples' perceptions of changes. What might be considered reactions to external pressures may be better understood by focusing on individuals and groups as agents in their own rights, trying to understand drives and motivations behind actions, and understanding the fields of action that are open to them with particular social and cultural resources. Any village or town is an integrated part of a larger world, and the imaginings of individual actors and groups, as well as their material and symbolic resources and possibilities, define the social field that we observe. What is increasingly obvious in Maniitsoq, and elsewhere in Greenland and other Arctic societies, is the development of practices and understandings of the world that appear to be in important respects urban, conditioned by the growing influence on local culture-behavioural norms, language, food, music and fashion - of interaction with foreign life styles.

To summarise, it looks very much as if a process of urbanisation is underway approximating to that which happened in Europe, with people moving into towns to look for better opportunities. Although the urban-rural continuum may not, at first sight, apply to the Arctic, given the absence of agriculture, there are extensive hinterlands to which towns stand in similar relations of interdependence as their European predecessors (Redfield 1947). What is more, since images of southern cities are already part of northern imaginations and represent options to be chosen under particular circumstances, the South may be seen as part of such a continuum, either physically or mentally. In this process, practices, understandings and knowledge characteristically associated with the hunting and fishing mode of life are transformed. On moving into urban apartments, extended families have become slimmed down to resemble nuclear families; hunters have become wage workers or crew members on trawlers; their wives have gone to work in the fish factory or the store. Some villagers have never resumed hunting and fishing after they left their original settlement, 
whereas others have done so as best they can in the new place: living off the land, yet living in a town, is an important way of life in the Arctic (Rasing 1999).

\section{What do we mean by urbanism?}

The city has been an object of sociological reflection since late 19th and early 20th centuries thinkers described the difference between rural, closed corporate communities and the cities of industrial capitalism, focusing on different kinds of social integration and the implications of societal form and content for individuals (Durkheim 1947[1893]; Simmel 1950[1903]; Tönnies 2005[1887]). These perspectives still influence how we think about urbanisation, the city and urban life, and the towncountry divide (Hannerz 1980; Leeds 1984). The idea that urban living exemplifies the predicament of individuals under modernism comes out clearly in Simmel's classic The Metropolis and Mental Life, in which the city is contrasted to the small town and rural life. The city creates psychological conditions that produce individuality, marked by intellectualism, rationalism, emotional reserve and sophistication. This is an ethos of indifference that is conducive to both freedom and loneliness, whereas small town life rests more upon deeply felt and emotional relationships and the social control of community members.

The modern city is, in a sense, the archetypical urban condition, and ways of thinking about this kind of city exert a strong hold on our approach to urbanism. This representation of the city is so ingrained in our commonsense concepts, that it is difficult to even talk about urbanism without implying, at least, the usual attributes of the city ${ }^{4}$. In that sense a small town is less urban than a large town, which again is less urban than a metropolis. Urban, in other words, is a graded concept. For this, if for no other, reason, much discussion of "the urban" and "urbanisation" is ethnocentric, based on historically and culturally specific urban phenomena and urban forms of integration (Leeds 1994: 51). What we mean by urban has implications for the way we look at people and relationships, for what we observe and see. Much anthropological writing about social change and urbanisation, attempts to formulate, therefore, a generic definition of urbanism (see Hannerz 1980 for an authoritative review). Tracing the development of urban anthropology, Hannerz develops an approach to an "anthropology of the city," which, with the works of Leeds (1994), is the main theoretical inspiration here. I will present these perspectives only briefly, in order to proceed to a discussion of their theoretical and methodological relevance in studies of social change and urbanisation in the Arctic.

Returning to my opening reflections on the APS and the AHDR, and to my ethnographic observations of what appears to be urban life in Maniitsoq, a working definition of urban is needed in order to be able to discuss critically urbanisation, social change under urban conditions, emigration from the North, and migration between northern communities. We need to know when migration leads to urbanisation, and

4 Earlier, I used the words "bustling" and "fluid" to signal urbanity. 
what provokes it. If migrants were already in open contact with the city from the outset, when did urbanisation begin? When people return to their communities of origin, if they do, will a process of "urbanisation in reverse" begin, or does it take an increase in population for a settlement to be urban?

As already discussed, the APS defines an urban area as a settlement with an absolute number of at least 1,000 inhabitants, and a population density of at least 400 per square $\mathrm{km}$. As indicated by Ludger Müller-Wille (pers. comm.), using this criterion, there are many places, in Nunavut, for example, that can be called urban areas. It depends on how density is calculated; if it is concentrated on built-up areas, a density of 400 people per square $\mathrm{km}$ is easily reached. Iqaluit, with 6,000 inhabitants, plus temporary residents, is, on this criterion, clearly highly urbanised, as is Nuuk. If the calculation is based on municipalities, including territory outside built-up areas, then the result will be different. Obviously, however, urbanisation is not a matter of density alone, but also involves other social, economic and political factors (see also Müller-Wille 1978). Number and density have been defining criteria of urbanisation since the Chicago School studied city growth in the 1920s. In his essay "Urbanism as a Way of Life," Wirth (1938: 8, emphasis added) defines the city as a "relatively large, dense, and permanent settlement of socially heterogeneous individuals." Size and density influence the nature of social relations, making interaction superficial and increasing social differentiation and the specialisation of tasks. This gives rise to the third defining characteristic of the city, heterogeneity, and also to a specific urban ethos, in the preponderance of secondary contacts and relationships that are "impersonal, superficial, transitory, and segmental" (ibid.: 12). Thus urbanism is more than the physical, delimited space of the city. It is also more than merely immigration into cities and the incorporation of migrants into its system of life:

Urbanisation refers also to that cumulative accentuation of the characteristics distinctive of the mode of life associated with the growth of cities, and [...| to the changes in the direction of modes of life recognized as urban which are apparent among people, wherever they may be, who have come under the spell of the influences which the city exerts by virtue of the power of its institutions and personalities operating through the means of communication and transportation" (Wirth 1938: 5; emphasis added).

This influence, which the city also exerts on people not living in the city but perhaps under its cultural influence, is termed by Leeds (1994: 57) "social urbanisation." The phenomenon is part of the way that urbanisation works in modern, capitalist, state societies, where towns and cities are nodal points in an overall, centralized and hierarchical structure (ibid.: 71). Through exchange and administration issuing from a centre-involving everything from judicial principles to merchandisepeople in the urban hinterland experience social urbanisation. From this perspective, the "urban" is not based in numbers and densities, or in ways of life, but in structures and processes connected to hierarchies of power (economic, judicial, administrative, etc.). This is the "central place theory" elaborated by Leeds (1994: 72ff). It is closely related to his theory of urban society: "any society which has in it what we commonly call 'towns' or 'cities' is in all aspects an 'urban' society, including its agricultural and 
extractive domains" (ibid.: 71). In other words, towns and cities are not secluded social spaces, but expressions of a societal form, the modern state, in which they function as nodal points for trans-local communication at all levels. The patterns of centricity that develop-how urban centres relate to and are related to by their hinterlands-are connected to their specialisms and the roles they fulfil. In the words of Hannerz (1980: 91-98), it is a matter of that which made the centre central in the first place.

Introducing Leeds' ideas on central place at this point opens up a new arena for talking about urbanisation in which it can be proposed that everybody living in a modern state society is living in an urban society. As will become clear in the section where I discuss the urbanisation that has occurred in Greenland and Nunavut, and how this relates to welfare states and neo-colonial state policies towards their northern citizens, the central place theory offers a framework within which to think about urbanisation in the Arctic in new ways. It also presents a comparative perspective for analysing the structures and processes that are at work in northern communities. Looking at Hannerz' work on an anthropology of the city (Hannerz 1980: 3), the case is -if not clear, because I prefer to keep this tentative still-open. Hannerz' most general understanding of the city brings together centralism and specialism. That is, what makes the city central is its role in a context which also supports the social life of the city. A key concept is heterogeneity. Inspired by Wirth, Hannerz (1980: 66ff) assumes that the urban society is constructed in terms of roles and relations, and that people individually have a repertoire of roles drawn from an inventory identified in the urban community in question (ibid.: 317), depending on availability according to gender, age, class, education, family relations, etc. Since roles create different kinds and qualities of relations, mapping a community's role inventory and individual members' repertoires provides a formal framework for identifying and describing empirical material. These relationships are observed in concrete situations. Urbanism as the way of life in cities may be observed and described only in real situations. In other words, the approach will be limited to the field defined by the focus of study and not by demands to describe the total role inventory.

It is a far shot from the purpose and scope of this article to discuss how we might make this approach operational. Rather, in seeing Arctic societies as urbanised, my point is to seek inspiration in methodologies developed in what are usually considered to be more complex settings than Arctic small-scale communities; to look into questions designed to challenge our field of study, see new connections and grasp new patterns; to describe the particular characteristics of Arctic urbanism that will help us describe the context in which people find themselves, the choices they have to make and their implication for society and culture; to make the material amenable to comparative analysis within urban anthropology generally, in a way that can encourage greater coherence and wider relevance in Arctic social science research. As will be described, the history of urbanisation and the role of towns in the Arctic differ in important respects from the ways that towns and cities grew up in America and Europe during the era of industrial capitalism, which provided the models for urban sociologists. Centralism and specialism have other roots and effects in Nunavut and Greenland. 


\section{Arctic perspectives from Greenland and Nunavut}

Greenland and Nunavut achieved Home Rule in 1979 and 1999, respectively. In both, the country's Indigenous inhabitants are in the majority. The histories of Nunavut and Greenland have been structurally similar, yet very different when it comes to process and content. Both have experienced colonial domination from the South; Canada and Denmark, respectively. Inuit in the Canadian Arctic came into direct contact with Southerners, traders and missionaries, between the mid-19th and the early 20th century, when trade and mission stations were established in the region (Paine 1977). Greenlandic Inuit were colonised more than a century earlier, and were part of a quite tightly structured colonial state by the mid-19th century (Sveistrup and Dalgaard 1945). As early as the latter part of the 18th century, probably no Inuit group in West Greenland between Upernavik in the North and Frederikshaab in the South was uninfluenced by colonialism (Bobé 1936: 67).

In Arctic Canada and in Greenland, the fact of a southern presence was soon reflected in the yearly round of hunting activities, as well as in the location of camps and settlements during the year. These activities were influenced by when ships were known to arrive, or when particular goods were needed. Greenlanders especially were objects to a concerted effort by trade managers to ascertain the efficacy of hunting so that it might provide a regular surplus to trade (Sveistrup and Dalgaard 1945). Both Greenlandic and Canadian Inuit remained hunters, in Canada evolving into trappers in the early 20th century (Damas 2002). Whereas most Greenlandic hunters lived in permanent villages from around 1850 (Sveistrup and Dalgaard 1945), Canadian Central Arctic Inuit kept up a degree of semi-nomadism well into the 20th century, albeit as fur producers and organised with a focus on trapping as an important new technology. At intervals during the year, trappers would come to the trading posts to exchange their furs for store goods and return to the camp, which varied from one, or a few, extended families, to 100 or more during the winter (Damas 2002). In Greenland, the Royal Danish Trade Company reached out for the hunters in outlying places through local employees who were in charge of stocks of basic provisions to be exchanged in return for hunting products, which were brought to the trade establishments by boat.

World War II brought great changes for both groups. In Canada a new national (Canadian) awareness of its North developed, occasioned by the northern military defence establishments, the collapse of the global market for furs and the concomitant economic crisis, fatal incidents of starvation in some Inuit regions, and deteriorating health conditions (ibid.). This new involvement and awareness caused a break with previous policy that had left it largely to the trading companies, the missions and the police (RCMP) to administer Canadian relations with the Inuit. What happened next was the extension of state welfare institutions to the North. Contact between Greenland and Denmark was cut during the war. Greenland's external relations were instead administered from New York and Nuuk, by special agreement with the Americans. This experience of freedom from colonial paternalism, followed by post-war international interest in colonialism's third world subjects, prepared the way for a new relationship between Greenland and Denmark. Social and other conditions had to be 
improved to put Greenlanders in a situation comparable to Danes, and in 1953 constitutional rights were extended to Greenlanders, as Danish citizens (Højlund 1972; Petersen 1975; Sørensen 1983).

Permanent settlement was a quite different process in the two regions. In Canada it was a relatively sudden development, involving a housing programme that was launched in the late 1950s, which settled the Inuit over the course of a few years (Graburn 1969: 219; Paine 1977). This process began originally on its own during the 1950 s, when some of the trade posts on the Arctic coast became loci of population aggregation. Others followed in the 1960s. In some places, the process had begun during the war, stimulated by the establishment of military posts, as at Frobisher Bay, now Iqaluit, the capital of Nunavut, with a population of 5,000 (Damas 2002: 57ff):

By the late 1960s, the Inuit living in these centres were well served [...] with access to good housing and associated services, health facilities at nursing stations, schooling for the children, and the ever-present safety nets of various welfare and other legislation arrangements. Nevertheless, economic and social problems remained. While hunting and trapping were carried out to some extent from the centralized communities, and seasonal employment was widespread, the desire to expand into a wage economy on a regular basis was thwarted by extensive unemployment. Alcohol-related problems were evident, and native autonomy or leadership was seriously underdeveloped (Damas 2002: 162-63).

In Greenland, by contrast, settlement in permanent villages began in the early 1800 s and was concluded about 1850. This established a structure of colonial establishments ("colonies"), villages and outposts that stayed unchanged until development schemes started around 1950. This initiated a period of explicit modernization by the Danish state, under consecutive reform schemes launched in 1950 and 1964 respectively (see Grønlandskommissionen 1950; Grønlandsudvalget af 1960 1964). The 1960s and 1970s was a period of massive changes. Towns became centres of construction work on a previously unknown scale, resulting in abrupt changes to their physical layout, with factories, roads and concrete apartment buildings. These were also the years of a determined policy of centralisation, intended to turn Greenland into an industrialised nation of fishermen living in a few towns on the west coast. Inhabitants of small settlements and villages were encouraged to move to larger centres, and places were closed down or investments withheld to encourage a concentration of the population in centres of industrial development, where modern educational and health establishments were available. None of this could have happened without massive inputs from southern personnel working as experts during construction, and in service and "social" jobs afterwards. At this time, the Canadian North and Greenland experienced what has been described as the period of its most direct colonial oppression, as the welfare system was developed and southern dominance was at its highest (Paine 1977; Sørensen 1983). It laid the ground for an ethnic nationalism that eventually brought Home Rule in both regions.

In this quick description of 50 years of the development of Inuit societies into "modern societies," I have stressed aspects of the processes of settlement in Arctic 
Canada and in Greenland that tell us something about the history of northern urbanisation, and the kinds of communities that resulted from this. These towns were created by State intervention, planned and partly executed in the South, and finally erected in the North by a work force that, to a large degree, came from outside (Kleivan 1969; Paine 1977). These workers came to build houses for families from closed down villages who were moving into towns, in Greenland, and for formerly mobile hunters and trappers who were moving into the newly erected settlement houses that cropped up around trading posts and military installations, in what is now Nunavut. But these settlements were not really, at the time of their creation, primarily intended to cater to the needs of their inhabitants. They were intended as solutions to the administrative and economic problems of the rulers, of people down South.

\section{Is the Arctic urbanising?}

I have begun to explore how we might move towards a better understanding of one of the broader processes, in Riches'(1990) terms, that are currently underway in the Arctic: the routinisation of settled ways of life in small to medium towns. Focusing on the "subjectivities" of urbanism (i.e., the knowledge and values people entertain, the choices they make, and the patterns these produce in particular contexts) rather than the "objectivities" of urbanisation, and looking at settlements as "central places," offers a way forward which is not tied to a fixed model of urbanisation. In particular, it makes no assumptions about size, density or urban structure. Rather, the focus is on relationships: within settlements and between settlements, their hinterlands, and wider state and global systems. This approach is very tentative, however. The central place perspective that I advocate does need to be made practical for research purposes. Similarly, whether or not it should include roles and inventories, as proposed by Hannerz (1980: 316-323), is a matter for discussion. However, such a broad approach has the potential to produce new insights that are not hampered by preconceived notions of tradition versus modernity. It also has the potential to guide empirical observation and description in the many different circumstances in which we find people in the Arctic: living in a small town, spending time during school or studies in a southern city, working in the remote home village with Internet-supported learning, travelling for international sports competitions, hunting from a high powered motor boat, travelling by skidoo supported by satellite navigation systems, and so on. These are all things that make Inuit societies modern. Canadian and Greenlandic Inuit live in villages, towns or hamlets, even cities. While these situations are often not obviously urban in all, or even many, details, a certain urban colouring is created by their integration into regional, State and global systems.

A final note should focus upon the development and diffusion among private users of communication technology that adds a new dimension to the organisation of social interaction (Christensen 2003). The possibility to communicate over long distances means that social relationships are not confined to the urban space, or, at least, that all kinds of dense relationships do not depend on physical proximity for their existence. In considering the usefulness of urbanisation and urbanism as conceptual references for 
social anthropology in the Arctic, the proliferation of technological media is not an occasion to dismantle the idea that the form of settlement plays a part in determining social interaction and experience. What is implied by the spread of modern media and electronic modes of communication, however, is that what Wirth (1938) pointed out is coming true and should be studied, namely the development of urbanism in places that are not urban in terms of their size and demographic density. Thus a more general notion of accessibility may be added to diversity as a defining criterion of urbanism (see Hannerz 1980).

Arctic societies are experiencing formidable changes in all aspects of their people's lives these years. The post-colonial period in both Greenland and Nunavutalbeit not with quite the same rhythms - have been much concerned with issues of strengthening culture, language and self-determination, as real-life political goals in a situation of radical economic and social change and as reservoirs for political imagery unfolded in the struggle for Indigenous rights. What has also been happening all these years, as an implication of this struggle, is the progressively expanding participation of Arctic residents in a global dialogue. This has been going on as talk proper, as local people and their regional and national political leaders have discussed and negotiated terms of the deals that were to be struck with the power holders. It has also been going on by way of communication of a more general kind that is carried on through the media, and in situations of economic change when individuals, families, or whole villages have had to move to another place or have had to settle down for good, not moving anywhere. The latter examples are also called urbanisation, and part of the historic colonial tradition which has been exploding during these years for many different reasons, some imposed on Arctic societies rather than chosen. It is important that scholars of the Arctic adopt a relational perspective that will direct attention to the contexts in which people feel compelled or motivated to act in particular ways. Such approach is about culture and competences as transmitted to the young generation, and about cultural innovation as a process worked by real people. If we do not approach "the Arctic" with a more comprehensive view of what produces it, we will never understand it.

\section{Acknowledgments}

I wish to thank Jens Dahl, Richard Jenkins, Ludger Müller-Wille, Frank Sejersen and Janne Bleeg Jensen for their suggestions and critical comments at various points while drafting the article. Any shortcomings are of course my own.

\section{References}

APPADURAI, Arjun

1990 Disjuncture and difference in the global economy, in Mike Featherstone (ed.), Global Culture, Nationalism, Globalisation and Modernity, London, Sage: 293-310.

IS THE ARCTIC REALLY URBANISING?/27 
BOBÉ, Louis

1936 Opdagelsesrejser til Grønland 1473-1806, Meddelelser om Grønland, 55.

CHRISTENSEN, Neil Blair

2003 Inuit in Cyberspace, Copenhagen, Museum Tusculanum Press.

CSONKA, Yvon and Peter SCHWEITZER

2004 Societies and cultures: Change and persistence, in Niels Einarsson, Joan N. Larsen, Annika Nilsson and Oran R. Young (eds), Arctic Human Development Report, Akureyri, Stefansson Arctic Institute: 45-68.

DAHL, Jens

1985 New political structure and old non-fixed structural politics in Greenland, in Jens Brøsted, Jens Dahl, Andrew Gray, Hans Christian Gulløv, Georg Henriksen, Jørgen B. Jørgensen and Inge Kleivan (eds), Native Power. The Quest for Autonomy and Nationhood of Indigenous Peoples, Bergen, Universitetsforlaget: 172-187.

1986 Arktisk selvstyre, Copenhagen, Akademisk Forlag.

2000 Saqqaq, Toronto, Buffalo, London, University of Toronto Press.

DAMAS, David

2002 Arctic Migrants/Arctic Villagers, Montréal, McGill-Queen's University Press.

DORAIS, Louis-Jacques

1997 Quaqtaq, Toronto, Buffalo, London, University of Toronto Press.

DURKHEIM, Émile

1947[1893]Division of Labour in Society, New York, Simpson, Macmillan.

DYBBROE, Susanne and Poul B. MØLLER

1981 Fanger/fisker - lønarbejder? En undersøgelse af sammenhoengene mellem fangst og lønarbejde i Godhavn, 1976 og -77, Aarhus, Aarhus University, Department of Anthropology and Ethnography.

EINARSSON, Niels, Joan N. LARSEN, Annika NILSSON and Oran R. YOUNG (eds) 2004 Arctic Human Development Report, Akureyri, Stefansson Arctic Institute.

FIENUP-RIORDAN, Ann (with William TYSON, Paul JOHN, Marie MEADE and John ACTIVE)

2000 Hunting Tradition in a Changing World, New Brunswick and London, Rutgers University Press. 
FOGEL-CHANCE, Nancy

1993 Living in both Worlds: 'Modernity' and 'Tradition' among North Slope Inupiaq Women in Anchorage, Arctic Anthropology, 30(1): 94-108.

GRABURN, Nelson H. H.

1969 Eskimos Without Igloos, Boston, Little, Brown and Company.

\section{GRØNLANDSKOMMISSIONEN}

1950 Grønlandskommissionens betcenkning, 5, I: Erhvervsmcessige og økonomiske forhold ('Report of the Greenland commission, 5, I: Trade and economic conditions'), Copenhagen, Grønlandskommissionen.

\section{GRØNLANDSUDVALGET AF 1960}

1964 Betcenkning fra Grønlandsudvalget af 1960 ('Report of the Greenland committee of 1960’), report no. 363, Copenhagen, Ministeriet for Grønland.

HANNERZ, Ulf

1980 Exploring the City, New York, Columbia University Press.

HONIGMANN, John J. and Irma HONIGMANN

1965 Eskimo Townsmen, Ottawa, University of Ottawa, Canadian Research Centre for Anthropology.

1970 Arctic Townsmen: Ethnic Background and Modernization, Ottawa, Saint Paul University, Canadian Research Centre.

HØJLUND, Niels

1972 Krise uden alternativ, Copenhagen, Gyldendal.

KISHIGAMI, Nobuhiro

1999 Why do Inuit move to Montreal? A research note on urban Inuit, Études/Inuit/Studies, 23(1-2): 221-227.

2002a Inuit identities in Montreal, Canada, Etudes/Inuit/Studies, 26(1): 183-191.

2002b Urban Inuit in Canada, Indigenous Affairs, 3-4/02: 54-59.

2006 Inuit social networks in urban settings, in Pamela Stern and Lisa Stevenson (eds), Critical Inuit Studies. An Anthology of Contemporary Arctic Ethnography, Lincoln and London, University of Nebraska Press: 206-216.

KLEIVAN, Helge

1969 Dominans og kontrol i moderniseringen af Grønland, in Jan Hjarnø (ed.) Grønland i fokus, Copenhagen, Nationalmuseet: 141-166. 
LEEDS, Anthony

1994 Cities, Classes, and the Social Order, edited by Roger Sanjek, Ithaca and London, Cornell University Press.

MÜLLER-WILLE, Ludger

1978 Population Concentration in Arctic and Subarctic Ethnic Groups, in Ludger Müller-Wille, Pertti J. Pelto, Linna Müller-Wille, and Regna Darnell (eds), Consequences of Economic Change in Circumpolar Regions, Edmonton, University of Alberta, Boreal Institute for Northern Studies, Occasional publication, 14: 123-136.

NUTTALL, Mark

1994 Arctic Homeland. Kinship, Community and Development in Northwest Greenland, London, Belhaven Press, Cambridge, Scott Polar Research Institute.

PAINE, Robert

1977 The path to welfare colonialism, in Robert Paine (ed.), The White Arctic. Anthropological Essays on Tutelage and Ethnicity, St-John's, Memorial University of Newfoundland, Institute of Social and Economic Research: 728.

PETERSEN, Finn

1975 Grønlandssagens behandling $i$ FN 1946-54, Odense, Odense Universitetsforlag.

RASING, Willem C.E.

1999 Hunting for identity. Thoughts on the practice of hunting and its significance for Iglulingmiut identity, in Jarich Oosten and Cornelius Remie (eds), Arctic Identities. Continuity and Change in Inuit and Saami Societies, Leiden, Universiteit Leiden: 79-108.

RICHES, David

1990 The force of tradition in eskimology, in Richard Fardon (ed.), Localizing Strategies. Regional Traditions of Ethnographic Writing, Edinburgh, Scottish University Press: 71-89.

REDFIELD, Robert

1947 The folk society, American Journal of Sociology, 52: 293-308.

ROBERT-LAMBLIN, Joëlle

1999 La famille, le village, la ville: Dynamique du changement social au Groenland oriental de 1960 à 1990, Études/Inuit/Studies, 23(1-2): 35-53. 


\section{ROBERTSON, Roland}

1997 Glocalization: Time-space and homogeneity-heterogeneity, in Mike Featherstone, Scott Lash and Roland Robertson (eds), Global Modernities, London, Sage: 25-44.

\section{SIMMEL, Georg}

1950[1903]The metropolis and mental life, in The Sociology of Georg Simmel, edited by Kurt H. Wolff, Glencoe, The Free Press: 409-424.

\section{STATISTICS CANADA}

2003 Aboriginal Peoples Survey 2001 - Initial Findings: Well-being of the NonReserve Aboriginal Population, Catalogue no. 89-589, Ottawa, Statistics Canada.

\section{SVEISTRUP, Poul P. and Sune DALGAARD}

1945 Det danske styre af Grønland 1825-1850, Meddelelser om Grønland, 145(1).

SØRENSEN, Axel Kjær

1983 Danmark-Grønland $i$ det 20. århundrede - en historisk oversigt, Copenhagen, Nyt Nordisk Forlag Arnold Busck.

SØRENSEN, Bo Wagner

2003a Sød musik eller mislyd i Grønlands hovedstad?, Humaniora, 2: 8-11.

2003b Et stykke Danmark på klipper? Nuuk set udefra og indefra, Jordens folk, 3: 4-9.

2003c Nuuk: Fremmedgørelse i storbyen?, Tidsskriftet Grønland, 1: 25-40.

$2005 \quad$ Nuuk, Tidsskriftet Antropologi, 48: 185-200.

TÖNNIES, Ferdinand

2005[1887]Gemeinschaft und Gesellschaft, Darmstadt, Wissenschaftliche Buchgesellschaft.

VALLEE, Frank G.

1962 Kabloona and Eskimo in the Central Keewatin, Ottawa, Department of Northern Affairs and National Resources, Northern Coordination and Research Centre.

VANSTONE, James W.

1962 Point Hope: An Eskimo Village in Transition, Seattle, University of Washington Press. 


\section{WENZEL, George}

1986 Canadian Inuit in a mixed economy: Thoughts on seals, snowmobiles, and animal rights, Native Studies Review, 2(1): 69-82.

\section{WIRTH, Louis}

1938 Urbanism as a way of life, American Journal of Sociology, 44(1): 1-24. 